\title{
Thermal treatment of sewage sludge - one of possible disposal methods
}

\begin{abstract}
Waste water treatment is a standard process in developed countries. It is intended to minimize the influence of waste water on the environment.

The treatment process produces various remains that are generally called sewage sludge. In general, the remaining material is treated physically to dewater the sludge to reduce the volume and mass before disposal. This treated sewage sludge has around $25 \%$ of dry solids.

The chemical and physical properties of the sewage sludge have to be monitored to determine the correct method of disposal. If the sewage sludge contains higher concentrations of heavy metals the only method for the disposal is thermal treatment.

This article will present possible technologies for sewage sludge thermal treatment and the experience of Slovene waste thermal treatment plant that incinerates sewage sludge.

Keywords: waste water treatment, sewage sludge, heavy metals, waste incineration.
\end{abstract}

\section{INTRODUCTION}

The sewage sludge (SS) differs in composition based on its process treatment stage:

- primary (physical) treatment SS,

- secondary (biological) treatment SS,

- tertiary treatment SS.

Different SS types have different pollution levels especially in terms of heavy metals. If the waste water originates from industry these pollution levels are generally higher.

In addition, other biological, physical and chemical parameters need to be monitored before taking final decision on methods for the final disposal.

In the past, the easiest way to dispose the SS was the deposition on fields and lawns. This waste material has long time been regarded as a fertilizer. Due to high organic, nitrogen, phosphorous and other micro elements content, all supporting plants growth, it was very desired by farmers.

The legislation has limited the input concentration values of dangerous substances in soil $[1,2]$ to avoid accumulation of heavy metals in the soil and transition into the plants thus into food circle.

The well-known method for SS treatment is digestion, either aerobic or anaerobic. The later produces biogas thus gas with appropriate calorific value for power and/or heat production. The remaining material, coming from digestion, changes mostly the properties of the organic part of the material. This in turn means the concentration of heavy metals rises, thus it is less likely to be able to deposit the remaining material on fields and lawn.

One of the most expensive but the safest method for disposal of sludge is incineration or co-incineration. With this process the material is sanitized, volume and mass are reduced and the calorific value of the waste is utilized.

The energy utilization of waste is justified in energy and environmental sense. In doing so there must be met all legal requirements that define the process of waste incineration or rather called waste to energy process $[3,4]$. Heat generated can be used to produce power (electricity), hot water for heating and cool media for cooling residential areas or for the industrial process.

Incineration of waste in a centralized system of larger capacity is environmentally, technically and economically feasible, thus a solution for waste to energy at the regional or national (multi regional) level.

Table 1 and Table 2 show the average composition of Slovene dried SS. The values are in ranges as the compositions vary and strongly depend on the origin.

Table 1 - Average chemical composition of the organic part of dried SS

\begin{tabular}{|l|c|c|c|c|c|c|}
\hline Element & Carbon & Hydrogen & Oxygen & Nitrogen & Sulfur & Chlorine \\
\hline Concentration [\%] & $25-50$ & $2-7$ & $10-25$ & $2-6$ & $0.2-2$ & $0,1-1$ \\
\hline
\end{tabular}

Author'address: Faculty of Mechanical Engineering, University of Maribor, Smetanova 17, Maribor, Slovenia
Received for Publication: 16. 05. 2014.

Accepted for Publication: 23. 07. 2014. 
Table 2 - Heavy metals and organic pollutants in dried SS

\begin{tabular}{|l|c|}
\hline \multicolumn{1}{|c|}{ Metal } & Concentration [ppm] \\
\hline Cadmium & $2-1500$ \\
\hline Cupper & $200-8000$ \\
\hline Nickel & $20-5000$ \\
\hline Zink & $600-20000$ \\
\hline Lead & $50-3600$ \\
\hline Mercury & $0,2-18$ \\
\hline Chromium & $40-14000$ \\
\hline Molybdenum & $1-40$ \\
\hline Arsenic & $3-30$ \\
\hline Selenium & $1-10$ \\
\hline Fluorine & $60-40000$ \\
\hline Organic pollutant & \\
\hline PAH & $0.01-50$ \\
\hline PCB & $0.2-10$ \\
\hline Pesticides & $0.1-10$ \\
\hline PCDD/F & $0-0.1$ \\
\hline
\end{tabular}

\section{TECHNOLOGIES FOR THERMAL}

\section{TREATMENT OF SEWAGE SLUDGE}

Not only SS but also other wastes from the waste water treatment process (swim scum, screenings, and extracted fats) are often incinerated.

Depending on the technology, the incineration plants are receiving partially dried sludge. The more dried SS requires less additional fuel than raw SS. The lower heating value (LHV) of the SS for auto thermal incineration lies above $6 \mathrm{MJ} / \mathrm{kg}$. Where raw SS material is treated the LHV between $2.2 \mathrm{MJ} / \mathrm{kg}$ and $4.8 \mathrm{MJ} / \mathrm{kg}$ are noted.
The need for additional fuel can be reduced by the use of efficient internal energy recovery systems e.g. recovery of heat form flue-gases to heat incineration air and/or the use of heat to provide SS drying. Used oil is the most commonly employed additional fuel in mono-sewage sludge incinerators. Heating oils, natural gas, coal, solvents, liquid and solid waste and contaminated air are also used.

Incinerators solely built for SS treatment are generally designed and operated at temperatures between 850 and $950{ }^{\circ} \mathrm{C}$. Temperatures below 850 ${ }^{\circ} \mathrm{C}$ are in conflict with legislation [2], while temperatures above $950{ }^{\circ} \mathrm{C}$ may result in ash melting and fusion. Gas residence times in excess of 2 seconds are employed. The temperature level achieved during incineration depends mainly on the energy content and the amount of sewage sludge to be treated and on the atmospheric oxygen level.

The next subchapters will describe the furnace systems functions according to different process technologies. The furnace structure, design, and operational technology of the incineration plant, the cleaning equipment, as well as the transport of different material flows, all have a significant influence on the resulting emissions.

\subsection{Multiple hearth incinerators}

For the incineration of SS multiple hearth incinerators are mainly applied. The multiple hearth furnace (Figure 1) consists of a cylindrical lined steel jacket, horizontal layers, and a rotating sleeve shaft with attached agitating arms. The furnace is lined with refractory bricks.

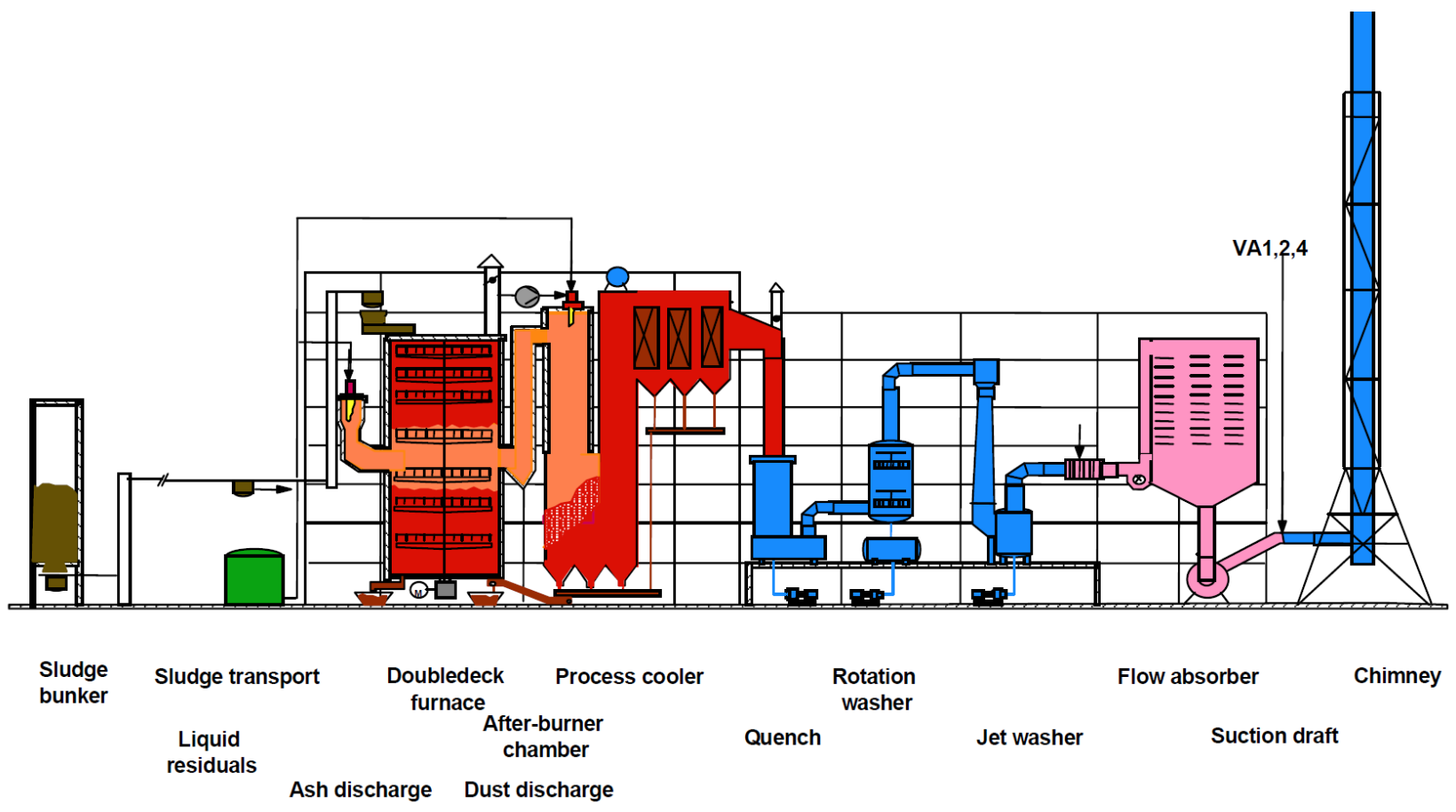

Figure 1 - Example of a SS incineration plant with a multiple hearth furnace [5] 
The number of trays for drying, incineration and cooling is determined based on the SS characterristics. The multiple hearth furnace is also equipped with a start-up burner, sludge dosing mechanism, circulation-, sleeve shaft- and fresh air - blowers. Sewage sludge is fed at the top of the furnace and moves downwards through the different hearths countercurrent to the combustion air, which is fed at the bottom of the furnace and resulting hot flue gases. The upper hearths of the furnace provide a drying zone, where the sludge gives up moisture while the hot flue gases are cooled. The incineration mainly takes place at the central hearths. The incineration temperature is limited to $980{ }^{\circ} \mathrm{C}$, as above this temperature the sludge ash melting and fusion temperature will be reached and clinker will be formed.

The combustion of organic sludge particles into $\mathrm{CO}_{2}$ and $\mathrm{H}_{2} \mathrm{O}$ occurs at temperatures between 850 and $950^{\circ} \mathrm{C}$. If the desired incineration temperature cannot be reached independently, a start-up burner is used for the support. As an alternative, solid auxiliary fuel can be added to the sludge. The ash is cooled to approximately $150{ }^{\circ} \mathrm{C}$ at the lower layers of the furnace with counter-flowing cool air and the ash is removed via the ash system. The flue gas that is produced is led through a postreaction chamber with a guaranteed residence time of two seconds.

\subsection{Rotary kiln incinerators}

Rotary kilns are very robust and they can incinerate almost any waste, regardless of type and composition. Operating temperatures of rotary kilns used for wastes range from around $500{ }^{\circ} \mathrm{C}$ (as a gasifier) to $1450{ }^{\circ} \mathrm{C}$ (as a high temperature ash melting kiln).

When used for conventional oxidative combustion, the temperature is above $850^{\circ} \mathrm{C}$. Generally the higher the operating temperature, the greater the risk of fouling and thermal stress damage to the refractory kiln lining.

The rotary kiln (Figure 2) consists of a cylindrical vessel slightly inclined on its horizontal axis. The vessel is located on rollers, allowing the kiln to rotate around its axis. The waste is conveyed through the kiln by gravity as it rotates. The residence time of the solid material in the kiln is determined by the horizontal angle of the vessel and the rotation speed: a residence time of between 30 to 90 minutes is normally sufficient to achieve good SS burnout. Additional firing (support combustion) using liquid waste or additional fuel may be carried out to maintain the temperatures required to ensure the complete conversion of the waste being incinerated.

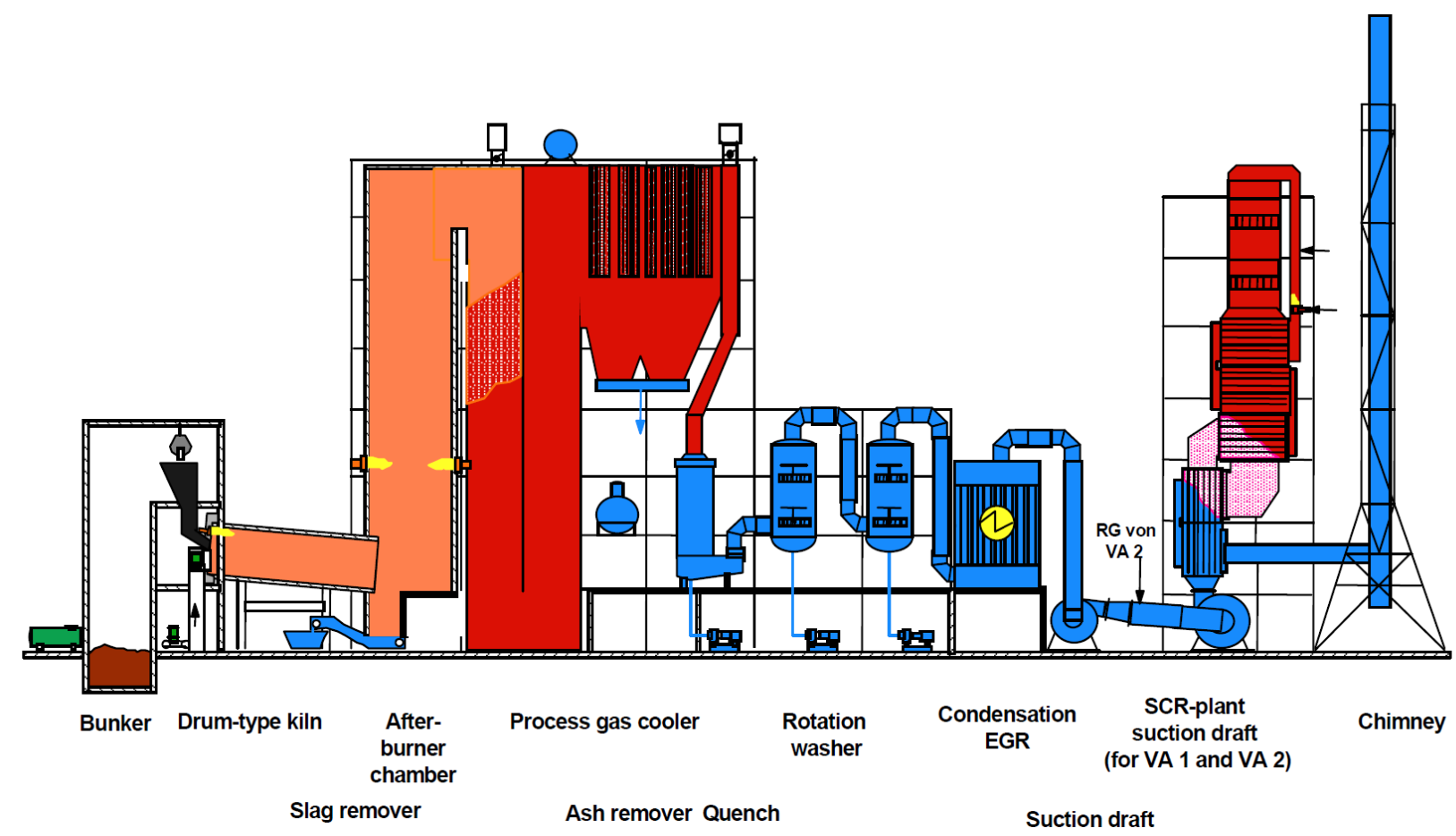

Figure 2 - Rotary kiln (drum-type) incineration system [5]

\subsection{Fluidized beds}

Fluidized bed incinerators are widely applied for the incineration of wastes in the form of small particles like refuse derived fuel (RDF) and SS. They have been used for decades, mainly for the combustion of homogeneous fuels. Among these 
are coal, raw lignite, sewage sludge, RDF and biomass (e.g. wood). The fluidized bed incinerator (Figure 3 ) is a lined combustion chamber in the form of a vertical cylinder. In the lower section, a bed of inert material, (sand or ash) on a distribution plate is fluidized with air. The SS for incineration is continuously fed into the fluidized sand bed from the top or the side. Preheated air is introduced into the combustion chamber via openings in the bedplate, forming a fluidized bed with the sand contained in the combustion chamber. The SS is fed to the reactor via a pump or a screw-tube conveyor. In the fluidized bed, drying, volatilization, ignition, and combustion take place. The temperature in the free space above the bed is between 850 and 950 ${ }^{\circ} \mathrm{C}$. Above the fluidized bed material, the free board is designed to allow retention of the gases in a combustion zone. In the bed itself the temperature is lower, and may be around $650{ }^{\circ} \mathrm{C}$ or higher. Because of the well-mixed nature of the reactor, fluidized bed incineration systems generally have a uniform distribution of temperatures and oxygen, which results in stable operation.

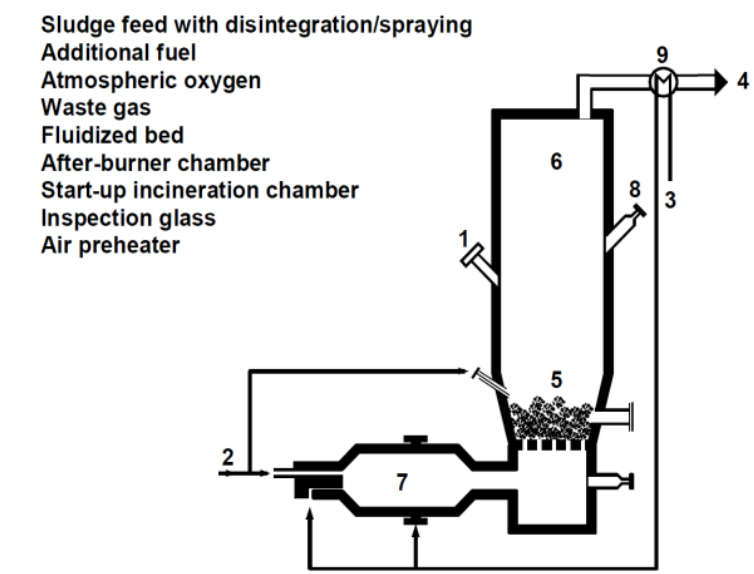

a)

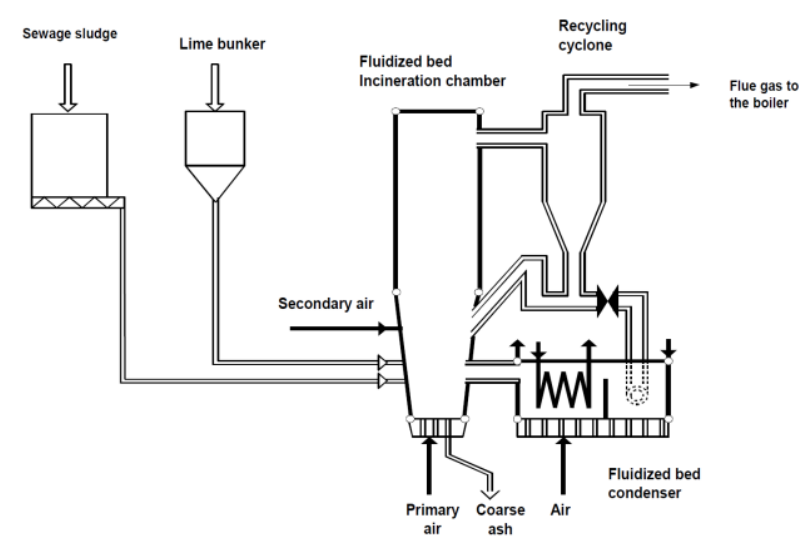

b)

Figure 3 - Schematic presentation of stationary/bubbling a) and circulating b) fluidized bed [5]

\subsection{Grate furnaces}

Grate furnace incinerators can be applied to treat all sorts of solid and pasty waste materials. The grate furnace (Figure 4) consists of a combustion chamber that has on the bottom grate system where incineration material lies on and combusts. The furnace is lined with refractory bricks. The length and wide of the grate and the inclination duration must correspond to the desired power output and characteristics of the incinerated material. The waste material and the flue gas movement in furnace can be designed as co-current or contracurrent, depending on the humidity of the incinerated material. The upper furnace part ensures necessary residence time of at least 2 seconds at minimum of $850^{\circ} \mathrm{C}$.

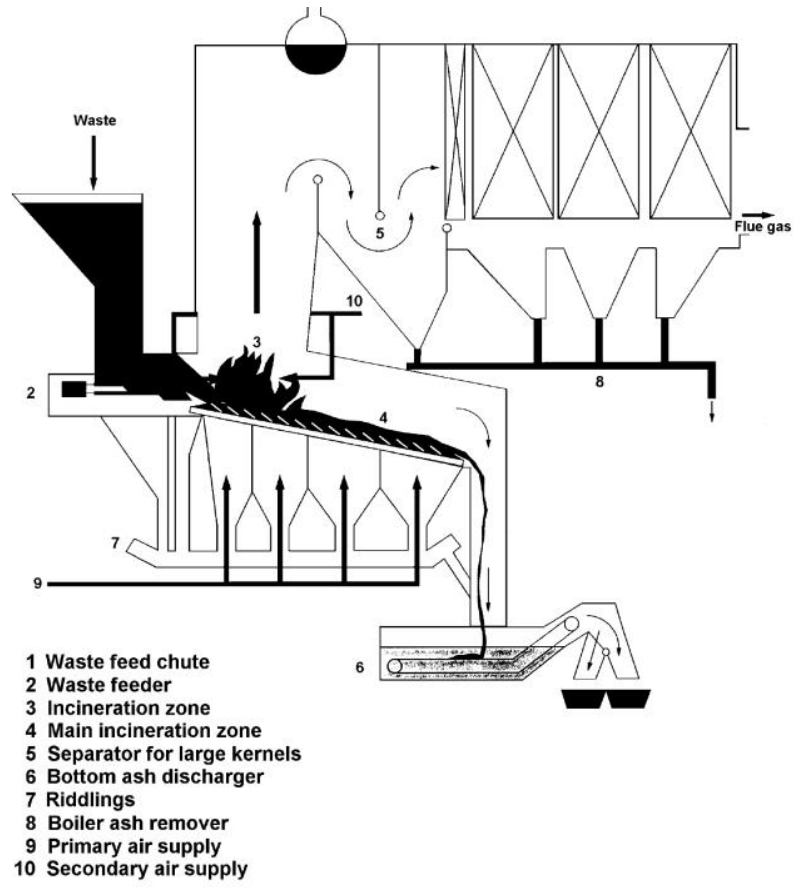

Figure 4 - Grate furnace and boiler of waste incineration plant [5]

Further down the flue gas flow the boiler and the flue gas treatment systems are positioned. The boiler cools down the flue gas and transfers the heat to water/steam or hot oil, utilized in power and/or heat production. The cooled down flue gas enters generally multi stage flue gas treatment system that cleans the gases to the quality, set by legislation [2].

For the startup procedure and if the desired incineration temperature cannot be reached independently, a start-up burner is used. In case of too low LHV of incinerated material the solid fuel can be added so that so that the mixture reaches necessary heating value for auto combustion with temperatures high enough and good solid fuel burn out. 


\section{CASE STUDY - SS INCINERATION AT CELJE WASTE - TO - ENERGY PLANT}

The waste thermal treatment at the Celje Waste - to -energy (WtE) plant called Celje district heating plant serves for RDF and SS thermal treatment.

The technology applied enables the released energy utilization (the combined heat and power production - CHP) from a light fraction of municipal solid wastes following separate collection (RDF) and dried SS. RDF has according to European waste code system [4] the designation $1912 \quad 10$ and the SS has 190805.

RDF, made up of paper, cardboard, plastic, foils, textile and wood is produced at the mechanical and biological treatment system. The SS from the Celje waste water treatment plant is only mechanically dried. Both these material streams represent the energy source for the Celje WtE plant.

The main reasons for the decision on the construction of the Celje WtE plant were:

- energy utilization of waste to cover part of the energy needs in the city of Celje,

- meet the strict requirements regarding the biodegradable carbon content in waste disposed of in the landfill for non-hazardous waste after the year 2008 and

- SS disposal generated in the Celje waste water treatment plant.

The WtE process annually covers approximately 20,000 tons of RDF and 5,000 tons of SS. The SS from the municipal waste water treatment plant with $30 \%$ of solids and heating value between 0 and $3 \mathrm{MJ} / \mathrm{kg}$.

The thermal power of the WtE plant is $15 \mathrm{MW}$ with 2,1 MW of power production. The power is supplied to the distribution network, while the heat energy is used in the district heating system for the city Celje. The plant is designed to operate 24 hours a day, 7 day a week and 8000 hours per year.

The waste thermal treatment process is conducted in the following stages:

- transport and dosage of RDF and SS to the combustion chamber in a ratio of up to $20 \%$ of SS and the rest RDF,

- the multi-step combustion of RDF and SS producing flue gas and ash,

- utilization (cooling) the flue gas and production of super-heated stem for the CHP production,

- flue gas treatment.

Figure 5 presents the operation confirmed values, recalculated on full load operation of Celje WtE plant.

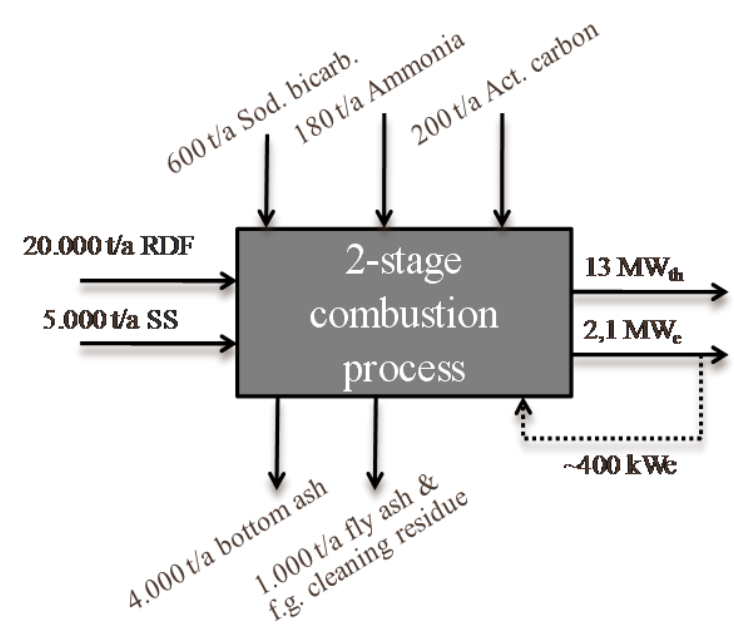

Figure 5 - Schematic presentation of mass and energy flow in Celje WtE plant

Average SS composition analysis treated in Celje WtE plant is presented in the Table 3.

Table 3 - The analysis results of SS from central waste water treatment plant.

\begin{tabular}{|l|c|c|}
\hline \multicolumn{1}{|c|}{ Parameter } & Result & Unit \\
\hline Water content & $70-85$ & $\%$ \\
\hline Combustion solid residue (ash) & $35-50$ & $\%^{*}$ \\
\hline Heating value & $9-16$ & $\mathrm{MJ} / \mathrm{kg}^{*}$ \\
\hline Nitrogen & $1-6$ & ${ }^{*}$ \\
\hline Organic carbon & $20-25$ & $\%^{*}$ \\
\hline Hydrogen & $3-4$ & $\%^{*}$ \\
\hline Oxygen & $25-45$ & $\%^{*}$ \\
\hline Sulfur & $0.5-1.0$ & ${ }^{*}$ \\
\hline Chlorine & $0.1-0.3$ & $\%^{*}$ \\
\hline Fluoride & $90-120$ & $\mathrm{mg} / \mathrm{kg}^{*}$ \\
\hline
\end{tabular}

* The results refer to dried matter at $105^{\circ} \mathrm{C}$.

By using state-of-the-art technology all environmental, technical and economic requirements and stipulations of the Environment Protection Act and the implementing regulations, along with the directive on the incineration of waste [2] are met. The plant is regarded as an IPPC plant and has such permit. [3]

Ash and slag from primary combustion chamber are not considered dangerous waste material, therefore are landfilled on local landfill site. Flue gas treatment residue contains increased quantities of heavy metals and salts. It is therefore classified as hazardous waste. Its disposal is carried out by third parties, which are authorized for export, as there are no hazardous waste landfill sites in Slovenia. 


\section{CONCLUSION}

SS is a waste and due to its organic part, it presents a source of energy. The energy utilization is possible with the appropriate incineration techniques. Such techniques with additional systems can create power and heat, which are distributed to the industry and/or citizens.

Utilization of SS in WtE plants means reducing greenhouse gas emissions, more rational energy management and no ground and soil contamination with heavy metals.

Operational data in case of Celje WtE in last four years show the following positive effects:

- the total quantity of up to 5,000 tons SS per year can be effectively incinerated with no additional fossil fuel,

- the mixture of SS towards RDF is unproblematic with this system to the ratio up to $20 \%$ of mass,

- the heat obtained from the incineration is used in the CHP production.

The produced heat is all year long used for the needs of the district heating in Celje. In heating season, complete produced heat is consumed by the district heating. The power is partially used for the facility's own consumption and the surplus is placed in the power distribution network.

\section{LITERATURE}

[1] Decree on the limit input concentration values of dangerous substances and fertilisers in soil (original: Uredba o mejnih vrednostih vnosa nevarnih snovi in gnojil v tla), Official Gazette, Republic of Slovenia, no. $84 / 2005$ in changes in Official Gazette no. 62/2008, 62/2008, 113/2009;

[2] Directive 2000/76/EC of the European Parliament and of the Council of 4 December 2000 on the incineration of waste; Official Journal L 332 , 28/12/2000 P. 0091 - 0111;

[3] Directive 2008/1/EC of the European Parliament and of the Council of 15 January 2008 concerning integrated pollution prevention and control, Official Journal L 24, 29/1/2008, P. 8-29;

[4] Directive 2008/98/EC of the European Parliament and of the Council of 19 November 2008 on waste and repealing certain Directives; Official Journal L 312, 22/11/2008 P. 0003 - 0030;

[5] Reference Document on the Best Available Techniques for Waste Incineration, Integrated Pollution Prevention and Control, European Commision, Joint Research Centre, Institute for Prospective Technological Studies, August 2006.

\title{
IZVOD
}

\author{
TERMIČKI TRETMAN KANALIZACIONOG MULJA \\ - JEDAN OD MOGUĆIH METODA ODSTRANJIVANJA
}

Prečišćavanje otpadnih voda je standardni proces u razvijenim zemljama. Namera je da se minimizira uticaj otpadnih voda na životnu sredinu. Ovaj proces tretmana proizvodi razne ostatke koji se uglavnom nazivaju muljem. Generalno, preostali materijal se fizički tretira da bi se smanjila zapremina i masa mulja pre odlaganja. Tako tretirani mulj ima oko $25 \%$ suve materije. Hemijske $i$ fizičke osobine mulja se moraju pratiti da bi se mogao utvrditi prihvatljiv metod odstranjivanja . Ako mulj sadrži veće koncentracije teških metala jedini metod za odstranjivanje je termički tretman. Ovaj članak će predstaviti moguće tehnologije za termički tretman mulja i iskustvo slovenačkog objekta za termički tretmana otpada, koji spaljuje mulj.

Ključne reči: prečišćavanje otpadnih voda, kanalizacioni mulj, teški metali, spaljivanje otpada.

Originalni naučni rad

Primljeno za publikovanje: 16. 05. 2014.

Prihvaćeno za publikovanje: 23. 07. 2014. 